\title{
PERAN PENGAWASAN KEPALA SEKOLAH TERHADAP KINERJA PENDIDIKAN KABUPATEN LEBAK BANTEN
}

\author{
Setiadin \\ Universitas Muhamamdiyah Bandung \\ doktor.dinsetiadin@umbandung.ac.id
}

\begin{abstract}
Performance of the Education Office is demanded to have work discipline in accordance with their duties, taking into account the factors that most determine the educational process in an area. This study examines the influence of the supervision of school principals on the work coordination of teachers of Vocational Middle School (SMKN) teachers as an understanding of improving education in Lebak Regency, Banten Province. The method used in this study is the explanatory method, with surveys. The sample consisted of 111 SMKN teachers in the Lebak Regency Education Office Environment in Banten Province using the Slovin formula. Data were analyzed quantitatively using the statistical formula of path analysis. The results showed that the supervision of school principals on the work discipline of the teachers of the SMKN Environment Department of Education in the Lebak Regency of Banten Province was $74.81 \%$. This influence is very strong because the work discipline of vocational school teachers is very much determined by the supervision of the principal. On this basis, the principal increases the discipline of teacher work by providing opportunities for discussion of teacher subject deliberation activities (MGMP) training and seminars and encouraging teachers to continue their education to a higher level with the subjects they support. In addition, schools must also supervise and follow the steps and in accordance with school management guidelines.
\end{abstract}

Keywords : Supervision, School Principal, Educational Performance, Lebak Regency

\begin{abstract}
Abstrak - Kinerja Dinas Pendidikan dituntut memiliki disiplin kerja yang baik sesuai ketentuan tugasnya, mengingat keberadaannya sebagai faktor yang paling menentukan keberhasilan proses pendidikan di suatu daerah. Penelitian ini mengkaji tentang pengaruh pengawasan kepala sekolah terhadap disiplin kerja guru Sekolah Menengah Kejuruan Negeri (SMKN) sebagai gambaran kinerja pendidikan di Kabupaten Lebak Provinsi Banten. Metode yang digunakan dalam penelitian ini adalah metode eksplanasi, dengan pendekatan survei. Sampel terdiri dari 111 orang guru SMKN di lingkungan Dinas Pendidikan Kabupaten Lebak Provinsi Banten dengan menggunakan rumus slovin. Data dianalisis secara kuantitatif dengan menggunakan rumus statistik pathanalisis. Hasil penelitian menunjukkan bahwa pengawasan kepala sekolah terhadap disiplin kerja guru SMKN lingkungan Dinas Pendidikan Kabupaten Lebak Provinsi Banten sebesar 74,81\%. Pengaruh tersebut dinilai sangat besar atau sangat kuat sehingga disiplin kerja guru SMKN tersebut sangat ditentukan oleh pengawasan kepala sekolahnya. Atas dasar ini maka kepala sekolah berupaya meningkatkan disiplin kerja guru dengan cara memberi kesempatan mengikuti kegiatan musyawarah guru mata pelajaran (MGMP) pelatihan dan seminar serta mendorong guru melanjutkan pendidikan ke jenjang yang lebih tinggi dengan mata pelajaran yang diampunya. Selain itu kepala sekolah hendaknya melakukan pengawasan secara lebih baik lagi dengan memperhatikan langkah-langkahnya dan sesuai dengan pedoman manajemen sekolah.
\end{abstract}

Kata kunci : Pengawasan, Kepala Sekolah, Kinerja Pendidikan, Kabupaten Lebak

\section{PENDAHULUAN}

Pelaksanaan program pendidikan menengah kejuruan melibatkan banyak faktor yang secara langsung maupun tidak langsung mempengaruhi keberhasilannya. Pertama meliputi ruang belajar, peralatan praktek, ruang laboratorium, ruang perpustakaan dan lainnya yang disebut perangkat keras (hardware). Kedua meliputi kurikulum, program pengajaran, manajemen sekolah, sistem pembelajaran dan lainnya yang disebut perangkat lunak (software); sedangkan kategori ketiga meliputi hal-hal seperti kepala sekolah, guru, anak didik dan orang-orang yang terkait dalam proses pendidikan yang disebut perangkat pikir (brainware). Disiplin kerja penting dimiliki guru mengingat disiplin merupakan ciri 
kesuksesan seseorang dalam melakukan hal yang baik demi terwujudnya suatu tujuan (Covey, 2005:112). Pentingnya disiplin guru dalam melaksanakan tugas dan kewajibannya dimana pada praktiknya meliputi 3 (tiga) aspek yaitu sikap mental, pengetahuan tentang pekerjaan dan perilaku ketika melaksanakan pekerjaan(Atmosudirdjo, 1987:157-158).

Artinya guru dalam melaksanakan tugas dan kewajibannya harus memiliki sikap mental yang berupa ketaatan dirinya terhadap aturan kerja yang telah ditetapkan oleh sekolah, memiliki pengetahuan berkaitan dengan tugas atau mata pelajaran yang diampunya dan berperilaku sesuai dengan tuntutan tugas tersebut sebagai wujud tanggung jawab dirinya yang ia tunjukkan dengan menjadi inisiator setiap kegiatan sesuai dengan tuntutan tugas dan kewajibannya serta berusaha melaksanakannya, mengusahakan sumberdaya atau sarana dan prasarana yang diperlukan serta menginformasikan hasilnya (Beitler, 2006:145). Dalam realisasinya semua hal tersebut berupa ketaatan guru terhadap waktu pelaksanaan tugas dan kewajibannya, perasaannya terhadap tugas dan aturan yang mendasarinya, memiliki pengetahuan sesuai dengan tuntutan mata pelajaran yang diampunya, membuat silabi, membuat program tahunan dan program semesteran, membuat rencana program pengajaran (RPP), menjadi inisiator kegiatan berkaitan dengan tuntutan mata pelajaran yang diampu dan melaksanakannya serta berusaha melengkapi sarana dan prasarana yang diperlukan, membuat rancangan penilaian dan melaporkan hasilnya (Mulyasa, 2011:53-54). Tetapi pada kenyataannya hal tersebut masih berbeda dengan harapan seperti yang disajikan.

Kondisi tersebut tentu dinilai tidak baik bagi pelaksanaan pendidikan karena sebagaimana dijelaskan di atas tidak saja mempengaruhi efektivitas proses pembelajaran tetapi juga hasilnya yang mencakup output dan outcome (Rumiyati, 2010:21). Output dimaksud merupakan hasil belajar yang merefleksikan seberapa baik peserta didik mampu mengikuti proses pembelajaran yang secara ideal meliputi 3 (tiga) unsur yaitu kognitif, efektif dan psikomotor; sedangkan outcome bersifat jangka panjang baik yang berupa dampak bagi lulusan maupun masyarakat seperti berupa kesempatan pendidikan, kesempatan kerja dan pengembangan diri alumni. Tentu saja dengan kondisi kurangnya disiplin kerja guru seperti itu maka output dan outcome yang diperoleh peserta didik maupun masyarakat tidak sesuai dengan harapannya, sehingga wajar bila kontribusi pendidikan terhadap pembangunan IPM di Kabupaten Lebak Provinsi Banten kurang signifikan yang ditunjukkan oleh peringkatnya yang menduduki urutan ke 8 di provinsi tersebut.

Dilihat dari kajian Ilmu Administrasi Publik, disiplin kerja guru SMKN di lingkungan Dinas Pendidikan Kabupaten Lebak Provinsi Banten merupakan salah satu kajian ilmu tersebut. Ini mengingat guru SMKN di lingkungan dinas tersebut merupakan bagian dari aparatur pemerintah daerah atau dalam pandangan Djamin (1994:3) “... disebut dengan aparatur birokrasi daerah" sedangkan mempelajari birokrasi itu sendiri merupakan administrasi publik seperti dikemukakan oleh Henry (1988:29) bahwa "studi dan praktik mengenai birokrasi pemerintah disebut dengan administrasi publik". Dalam konteks ini, secara kausalitas banyak faktor yang mempengaruhi disiplin kerja guru. Salah satunya adalah pengawasan karena 
pengawasan menjamin hasil pekerjaan sesuai dengan rencana (Stoner, 1992:64). Dengan pengawasan dapat diketahui bagaimana guru melaksanakan tugas dan kewajibannya, bagaimana ia menggunakan sarana dan prasarana berkaitan dengan tugas dan kewajibannya, sikapnya ketika ia bekerja serta seberapa baik hasil pekerjaan tersebut mencapai tujuannya. Adapun yang bertugas mengawasi guru dalam melaksanakan tugas dan kewajibannya adalah kepala sekolah mengingat ia berperan sebagai educator, manager, administrator, supervisor, leader, entrepreneur dan climator maker (Suryosubroto: 2003:112-118). Adapun salah satu langkah yang dapat ditempuh menurut (Stoner, 1992:248) adalah dengan menetapkan standar dan metode mengukur kinerja. Idealnya, sasaran dan tujuan yang ditetapkan ketika berlangsung proses perencanaan dinyatakan dengan istilah yang jelas, dapat diukur termasuk batas waktunya.

Hal yang perlu diperhatikan dalam penetapan standar adalah bahwa standar dimaksud harus diperinci ke dalam istilah yang dapat dipahami dan diterima oleh setiap individu guru. Demikian pula metode yang diterapkan untuk mengukurnya harus dapat diterima sebagai yang akurat, sehingga secara keseluruhan standar dapat berfungsi secara efektif. Standar berkaitan dengan pelaksanaan guru meliputi ketentuan waktu memasuki dan ke luar kelas sesuai dengan mata pelajaran yang diampunya, Rencana Program Pengajaran (RPP) termasuk di dalamnya bahan ajar dan media yang diperlukan, silabus, rancangan penilaian siswa dan melaporkan hasilnya, program semesteran dan program tahunan (Mulyasa, 2011:53-54).

Berdasarkan uraian tersebut tampak pentingnya pengawasan oleh kepala sekolah terhadap disiplin kerja guru, atau pengawasan kepala sekolah berperan besar bagi terwujudnya disiplin kerja guru. Penelitian ini diarahkan untuk meneliti tentang pengaruh pengawasan kepala sekolah terhadap disiplin guru. Dengan dugaan bahwa 1 . Belum semua guru Sekolah Menengah Kejuruan Negeri (SMKN) di lingkungan Dinas Pendidikan Kabupaten Lebak Provinsi Banten berdisiplin dalam kerja; dan 2.Diduga belum memadainya pengawasan kepala sekolah berkaitan dengan disiplin kerja guru SMKN di lingkungan Dinas Pendidikan Kabupaten Lebak Provinsi Banten.

\section{METODE PENELITIAN}

Penelitian ini menggunakan metode kuantitatif yang menitikberatkan pada penggunaan data sebanyakbanyaknya dari populasi yang luas. Untuk keperluan pengolahan data dalam penelitian ini mengacu kepada hasil observasi dan hasil angket dari responden sebagai data primer penelitian dengan menggunakan skala Likert. Sugiyono (2007:107).

Sampel menurut Arikunto (2004:117) adalah bagian dari populasi” maka sampel penelitian ini adalah sebagian dari populasi yang diambil menggunakan metode Non-Probability Sampling. Metode yang digunakan adalah model Convenience Sampling yaitu suatu metode yang menarik anggota populasi tertentu saja. Convenience Sampling merupakan metode yang reliabel dan merupakan cara yang murah dan mudah untuk dilakukan (Cooper \& Schnidler, 2008 :397)

Berkaitan dengan hal ini, sampel ditetapkan dengan menggunakan rumus 
alokasi proporsional $15 \%$ dengan alasan kemudahan untuk dapat mewakili seluruh sekolah yang ada. Total sampel yang menjadi responden penelitian sebanyak 111 orang sehingga memenuhi kriteria analisis jalur yakni 100-200 responden.

Sementara variabel pada penelitian ini terdiri dua variabel yaitu variabel pengawasan kepala sekolah (X), dan variabel disiplin kerja guru (Y). Setiap variabel terdapat dimensi dan setiap dimensi mengandung indikator yang dijelaskan sebagai berikut:

1. Pengawasan kepala sekolah (variabel $\mathrm{X}$ ) adalah kegiatan yang dilakukan oleh kepala sekolah untuk menjamin agar pelaksanaan tugas guru sesuai dengan rencana yang telah ditetapkan. Variabel ini diturunkan ke dalam dimensi yang meliputi: menetapkan standar dan metode pengawasan, mengukur hasil kerja, menetapkan hasil kerja dan melakukan tindakan korektif.

2. Disiplin kerja guru (variabel $\mathrm{Y}$ ) adalah kesadaran dan kesediaan guru untuk menaati peraturan berkaitan dengan tugasnya yang telah di tetapkan. Variabel ini diturunkan ke dalam dimensi yang meliputi: sikap mental, pengetahuan berkaitan dengan pekerjaan dan perilaku ketika melaksanakan pekerjaan.

\section{HASIL DAN PEMBAHASAN}

Berdasarkan hasil penelitian, diperoleh kesimpulan yaitu terdapat pengaruh menetapkan standar $\left(\mathrm{X}_{1}\right)$, menilai hasil kerja $\left(\mathrm{X}_{2}\right)$, menetapkan hasil kerja $\left(\mathrm{X}_{3}\right)$ dan tindakan korektif $\left(\mathrm{X}_{4}\right)$ terhadap disiplin kerja guru. Untuk melihat lebih jauh tentang besar pengaruh langsung dan tidak langsung dari masing-masing sub variabel bebas terhadap variabel terikat, sehingga secara statistik dinyatakan berpengaruh maka berikut ini disajikan rincian pengaruh langsung dan tidak langsungnya.

Tabel 2. Hasil Uji Variabel

\begin{tabular}{|c|c|c|c|c|c|c|c|c|}
\hline \multirow[b]{2}{*}{ Variabel } & \multirow{2}{*}{$\begin{array}{l}\text { Koefisien } \\
\text { Jalur }\end{array}$} & \multirow{2}{*}{$\begin{array}{l}\text { Pengaruh } \\
\text { Langsung }\end{array}$} & \multicolumn{4}{|c|}{$\begin{array}{l}\text { Pengaruh tidak langsung } \\
\text { (melalui), dalam \% }\end{array}$} & \multirow{2}{*}{$\begin{array}{l}\text { Pengaruh } \\
\text { Tidak } \\
\text { Langsung }\end{array}$} & \multirow{2}{*}{ Total $(\%)$} \\
\hline & & & $\overline{X 1}$ & $\mathrm{X} 2$ & X3 & $\mathrm{X} 4$ & & \\
\hline$\overline{\mathrm{X} 1}$ & 0,192 & 3,69 & & 2,61 & 6,30 & 1,84 & 10,75 & 14,44 \\
\hline $\mathrm{X} 2$ & 0,223 & 4,97 & 2,61 & & 6,67 & 1,58 & 10,85 & 15,82 \\
\hline X3 & 0,413 & 17,06 & 6,30 & 6,67 & & 4,05 & 17,02 & 34,08 \\
\hline $\mathrm{X} 4$ & 0,173 & 2,99 & 1,84 & 1,58 & 4,05 & & 7,48 & 10,47 \\
\hline Total $\mathrm{P}$ & uh & & & & & & & 74,81 \\
\hline
\end{tabular}

Sumber: Data Primer diolah

1. Menetapkan standar $\left(\mathrm{X}_{1}\right)$ berpengaruh signifikan terhadap disiplin kerja guru (Y), sebagaimana telah disajikan pada uji-t dengan total pengaruh sebesar $14,44 \%$, terdiri atas pengaruh langsung sebesar $3,69 \%$ dan pengaruh tidak langsung sebesar10,75\%.

2. Menilai hasil kerja $\left(\mathrm{X}_{2}\right)$ berpengaruh 
signifikan terhadap disiplin kerja guru (Y), sebagai mana telah disajikan pada uji-t dengan total pengaruh sebesar $15,82 \%$, terdiri atas pengaruh langsung sebesar $4,97 \%$ dan pengaruh tidak langsung sebesar $10,85 \%$.

3. Menetapkan hasil kerja $\left(\mathrm{X}_{3}\right)$ berpengaruh signifikan terhadap disiplin kerja guru (Y), sebagaimana telah di sajikan pada uji-t dengan total pengaruh sebesar $34,08 \%$, terdiri atas pengaruh langsung sebesar $17,06 \%$ dan pengaruh tidak langsung sebesar17,02\%.

4. Tindakan korektif $\left(\mathrm{X}_{4}\right)$ berpengaruh signifikan terhadap disiplin (Y), sebagaimana telah di sajikan pada uji-t dengan total pengaruh sebesar $10,47 \%$, terdiri atas pengaruh langsung sebesar 2,99\% dan pengaruh tidak langsung sebesar $7,48 \%$.

Memperhatikan uraian di atas dan hasil analisis statistik penelitian, pengaruh pengawasan kepala sekolah terhadap disiplin kerja guru SMKN di lingkungan Dinas Pendidikan Kabupaten Lebak Provinsi Banten sebesar $78,81 \%$. Ini berarti kontribusi pengawasan kepala sekolah terhadap disiplin kerja guru SMKN di lingkungan dinas tersebut sebesar $78,81 \%$, atau sebesar $78,81 \%$ disiplin kerja guru SMKN tersebut ditentukan oleh pengawasan kepala sekolahnya. Kontribusi tersebut dinilai sangat besar atau sangat kuat yang menunjukkan tidak hanya kepala SMKN itu telah mampu melaksanakan pengawasan dengan baik sebagai salah satu fungsinya menjadi manajer yang bertanggungjawab atas keberhasilan sekolah yang dipimpinnya (Suryobroto, 2003:10), tetapi juga disiplin kerja guru SMKN tersebut sangat ditentukan oleh pengawasan kepala sekolahnya. Disiplin kerja guru SMKN di lingkungan Dinas pendidikan Kabupaten lebak Provinsi Banten yang ditunjukkan oleh sikapmentalnya yang berupa ketaatan terhadap aturan pekerjaan, memiliki pengetahuan berkaitan dengan pekerjaan yang telah dibebankan terhadapnya dan perilakunya ketika melaksanakan pekerjaan (Atmosudirdjo, 1982:85) sangat ditentukan oleh pengawasan kepala sekolahnya, sehingga semakin baik kepala sekolah tersebut melaksanakan pengawasan maka guru SMKN di lingkungan dinas itu akan semakin disiplin dalam bekerja.

\section{KESIMPULAN DAN SARAN Kesimpulan}

Berdasarkan analisis dan pembahasan mengenai pengaruh pengawasan kepala sekolah terhadap disiplin kerja guru sekolah menengah kejuruan negeri (SMKN) di lingkungan Dinas Pendidikan Kabupaten Lebak Provinsi Banten, maka dapat di tarik kesimpulan sebagai berikut:

1. Disiplin kerja guru SMKN di lingkungan Dinas Pendidikan Kabupaten Lebak Provinsi Banten sangat penting diwujudkan mengingat guru merupakan unsur yang penting menentukan efektivitas proses pembelajaran. Disiplin kerja guru SMKN itu yang dikaji dari sikap mental yang berupa ketaatannya terhadap aturan sekolah, pengetahuannya berkaitan dengan pekerjaan mengampu mata pelajaran dengan perilakunya ketika bekerja menujukan kondisi yang cukup. Artinya guru di SMKN tersebut dipandang memiliki ketaatan yang cukup terhadap aturan yang telah ditetapkan sekolah; memiliki pengetahuan yang cukup berkaitan dengan pekerjaannya dan memiliki perilaku yang cukup ketika melaksanakan tugasnya 
2. Disiplin kerja guru SMKN di lingkungan Dinas Pendidikan Kabupaten Lebak Provinsi Banten dipengaruhi oleh pengawasan kepala sekolahnya, mengingat ia merupakan manajer yang bertanggung jawab atas keberhasilan sekolah. Pengawasan kepala sekolah yang dikaji dari langkah-langkah pengawasan meliputi penetapan standar dan metode pengawasan, menilai hasil kerja, menetapkan hasil kerja dan melakukan tindakan korektif memiliki pengaruh sebesar $74,81 \%$ terhadap disiplin kerja guru. Pengaruh tersebut dinilai besar atau sangat kuat mengingat kepala sekolah telah dinilai baik dalam melaksanakan pengawasan. Kepala sekolah dipandang telah mampu menetapkan standar dan metode pengawasan, telah mampu menilai dengan baik hasil kerja guru, menetapkan dengan baik hasil kerja guru dan telah dengan baik melakukan tindakan korektif. Selain itu, besarnya pengaruh pengawasan kepala sekolah terhadap disiplin guru SMKN di lingkungan Dinas Pendidikan Kabupaten Lebak Provinsi Banten menunjukkan bahwa disiplin kerja guru tersebut sangat ditentukan oleh pengawasan kepala sekolahnya, sebab itu, semakin baik pengawasan kepala sekolah tersebut maka guru akan semakin disiplin dalam bekerja.

\section{Saran}

Bertitik-tolak dari kesimpulan penelitian di atas, maka saran dalam penelitian ini adalah:

1. Guru pada Sekolah Menengah Kejuruan Negeri (SMKN) di lingkungan Dinas Pendidikan Kabupaten Lebak Provinsi Banten merupakan unsur paling menentukan efektivitas proses pembelajaran di sekolah tersebut, maka perlu upaya untuk meningkatkan disiplin kerjanya.

2. Kepala SMKN di lingkungan Dinas Pendidikan Kabupaten Lebak Provinsi Banten merupakan manajer yang bertanggungjawab atas keberhasilan sekolah tersebut, maka ia bertanggung jawab melakukan upaya meningkatkan disiplin kerja guru. Upaya dimaksud meliputi:

a) memberikan kesempatan kepada guru untuk aktif mengikuti kegiatan yang di laksanakan oleh musyawarah guru mata pelajaran (MGMP);

b) memberikan kesempatan kepada guru untuk mengikuti pelatihan, seminar dan lokakarya berkaitan dengan pengampuan mata pelajaran;

c) memotivasi guru untuk mengikuti pendidikan ke jenjang yang lebih tinggi relevan dengan mata pelajaran yang diampunya;

d) melengkapi sarana dan prasarana pembelajaran yang diperlukan guru dalam melaksanakan tugasnya;

e) meningkatkan kesejahteraan guru yang berupa insentiffinansial; serta

f) menyeimbangkan beban-tugas mengajar di antara guru.

3. Mengingat kuatnya pengaruh pengawasan kepala sekolah terhadap disiplin kerja guru SMKN di lingkungan Dinas Pendidikan Kabupaten Lebak Provinsi Banten maka hendaknya kepala sekolah tersebut melaksanakan pengawasan dengan secara lebih baik lagi, kepala sekolah hendaknya:

a) menetapkan setandar dan metode pengawasan sesuai dengan pedoman dalam manajemen sekolah sebelum 
melakukan pengawasan dan mensosialisasikan kepada guru;

b) menilai hasil kerja guru secara lebih objektif agar hasilnya menjadi dasar bagi guru dalam memperbaiki baik proses maupun hasil kerjanya;

c) menetapkan dan mensosialisasikan hasil penilaian pekerjaan kepada setiap guru; dan

d) melakukan perbaikan terhadap hasil pekerjaaan guru berupa permerian contoh menyiapkan sarana dan prasarana pembelajaran, penggunaan metode pembelajaran, menilai dan mengaktifkan siswa dalam bejar.

\section{DAFTAR PUSTAKA}

Arikunto, Suharsimi, 1996. Prosedur Penelitian, Jakarta: Bina Aksara.

Atmosudirdjo, Prajudi, 1987. Beberapa

Pandangan Umum tentang Pengambilan Keputusa

(Decision Making), Jakarta: Ghalia Indonesia.

Beitler, Michael A., 2006. Srategic Organizational Change, Greensboro USA: Practitioner Press Internasional.

Cooper, \& Schindler., 2008. Business Research Method. $10^{\text {th }}$ Edition. McGraw-Hill International Edition. New York

Covey, Stephen, R., 2005. The $8^{\text {th }}$ Habith: Melampaui Efektivitas, Menggapai Keagunga (Penerjemah: Wandi S.

Brata dan ZeinIsa), Jakarta: PT.Gramedia.

Djamin,

Awaloedin.,1994.Penyempurna anAparaturdanAdministrasi $\begin{array}{cc}\text { Negara } & \text { Republik } \\ \text { Indonesia, Jakarta: } & \text { Yayasan }\end{array}$
Pembina manajemen Lembaga Administrasi Negara Republik Indonesia.

Henry,Nicholas

., 1988.AdministrasiNegarada
nmasalah-masalahkenegaraan
(Penerjemah: Luciana D.
Lontoh), Jakarta:Rajawali.

Hellrigel, Don and John W. Slocum, Jr., 1992. Management $6^{\text {Th }}$

Edition, New York: Addison-Wesley Publishing Company.

Manullang, M (1981) Dasar - Dasar Management, Ghalia Indonesia, Jakarta

Mulyasa, 2011, Manajemen dan Kepemimpinan Kepala Sekolah, Jakarta : Bumi Aksara.

Stoner, James A.F., 1992. Manajemen, (Penerjemah Alfonsus Sirait), Jakarta: Erlangga.

Suryobroto, 2010, Manajemen Pendidikan di Sekolah, Jakarta : PT Rineka Cipta.

Sugiyono, 2010, Metode Penelitian Administrasi, Bandung : Alfabeta. 